Please send trade news information and illustrations to Arveen Bajaj at the $B D J$, Nature Publishing Group, The Macmillan Building, 4-6 Crinan Street, London N1 9XW.

Trade news is provided as a service to readers using text and images from the manufacturer, supplier or distributor and does not imply endorsement by the $B D J$. Normal and prudent research should be exercised before purchase or use of any product mentioned.

\section{High speeds}

Manufactured from extremely light pure titanium, the Sirona $\mathrm{T} 1$ handpieces are ergonomically designed with a superior finish and are ideal for all preparation procedures where high speeds are required. Optimum fibre optic light of 25,000 lux ensures maximum illumination when carrying out treatment. In addition, triple spray rings on the handpiece direct irrigation to the operative site to ensure the preparation is kept free from heat and debris.

The Sirona T1 handpieces will withstand repeated sterilisation up to $135^{\circ} \mathrm{C}$ and have an improved spray ring that is exchangeable with the handpiece. The Sirona Click \&t Go feature enables the T1 handpieces to be used on other leading brands of handpiece couplings.

Reader response number $\mathbf{5 0}$

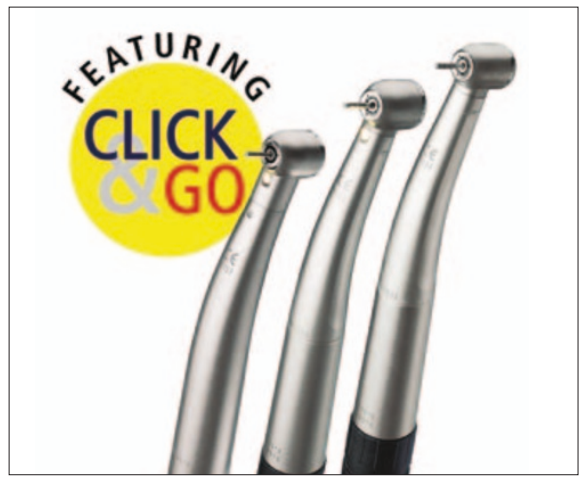

\section{Award winner}

The Sonicare toothbrush recently won FHM Magazine's Best Grooming Innovation Award and Philips Oral Healthcare is giving away 1,500 free copies of the April Edition of FHM Magazine for dental practices, waiting rooms to celebrate its success. The product was voted winner in the dental care category by readers of the 600,000 -strong circulation magazine and was considered to be the best product innovation. For more information contact 0800 0567222 or visit www.sonicare.co.uk Reader response number 52

\title{
Hygiene and safety
}

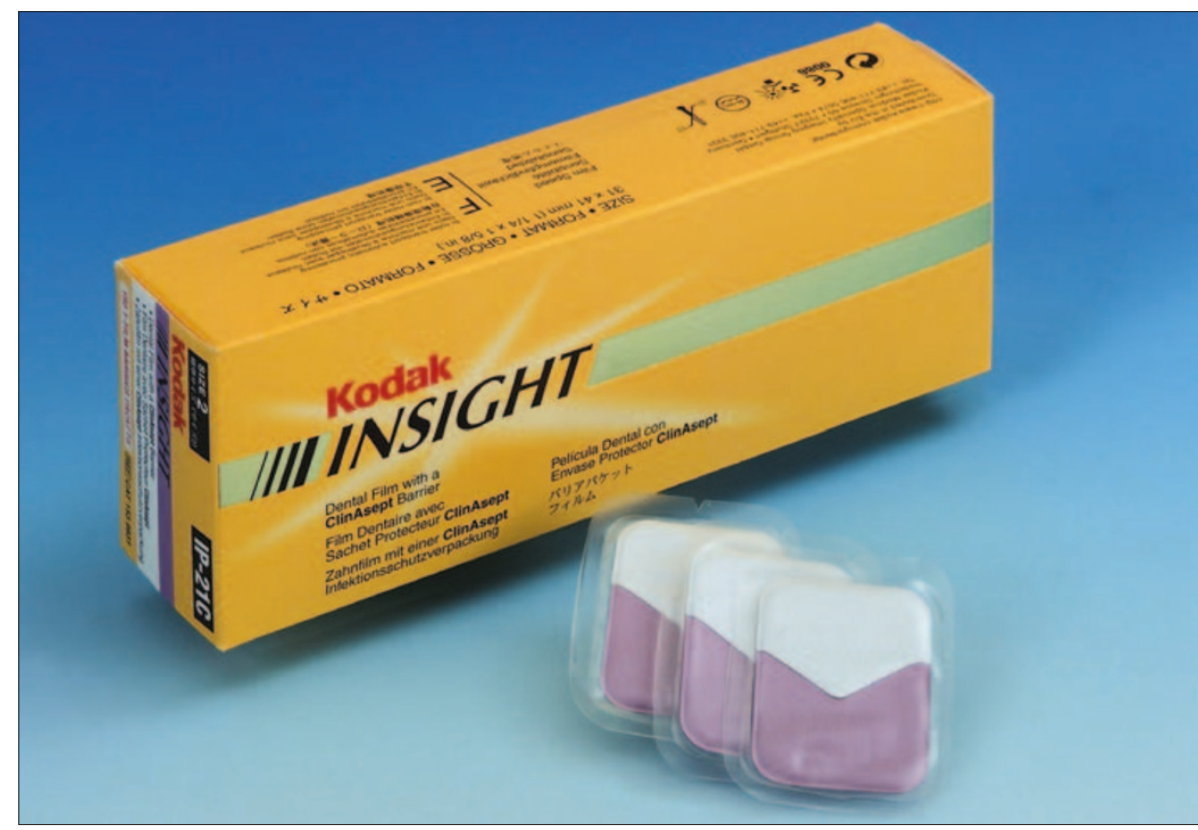

Kodak Dental Systems has designed ClinAsept packets for Kodak Insight Dental Films to improve hygiene and safety in the surgery for the benefit of both clinicians and patients. ClinAsept packets are designed to effectively minimise the risk of film cross-contamination during intraoral examinations and darkroom processing.

Presenting clear barriers to guard the film against the contaminants which may

\section{Help for needle phobic patients}

The Wand from DPS is a new product that can help patients who have needle phobia.

Topical anaesthetic is first applied to freeze the gum and then a tiny needle is gently introduced through the already-numb tissue to anaesthetise the surrounding area. The controlled flow also eliminates the 'bee sting' effect, which is descriptive of the pain associated with a surge of fluids into tissue.

Because less penetration force is required, needle advancement is almost effortless while the flow rate of the anaesthetic is controlled by a microprocessor occur in oral fluids, the ClinAsept packets can be easily removed after exposure and prior to processing. The Insight dental film in ClinAsept packets is available in two sizes, $3.1 \times 4.1 \mathrm{~cm}$ supplied in boxes of 100 single or double films, and $2.2 \times 3.5 \mathrm{~cm}$ supplied in boxes of 75 single or double films. It is also available in Periapical Super Poly-Soft packets, Periapical, Bite Wing and Occlusal paper packets.

Reader response number 51

instead of the pressure of the clinician's thumb, making it more precise.

The Wand technique is already being taught in many dental schools across the UK as a less traumatic and less intimidating method of administering anaesthetic. The disposable handpiece may be used with all $1.8 \mathrm{ml}$ and $2.2 \mathrm{ml}$ cartridges.

Reader response number 53

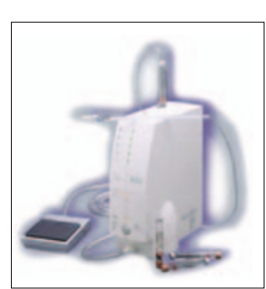



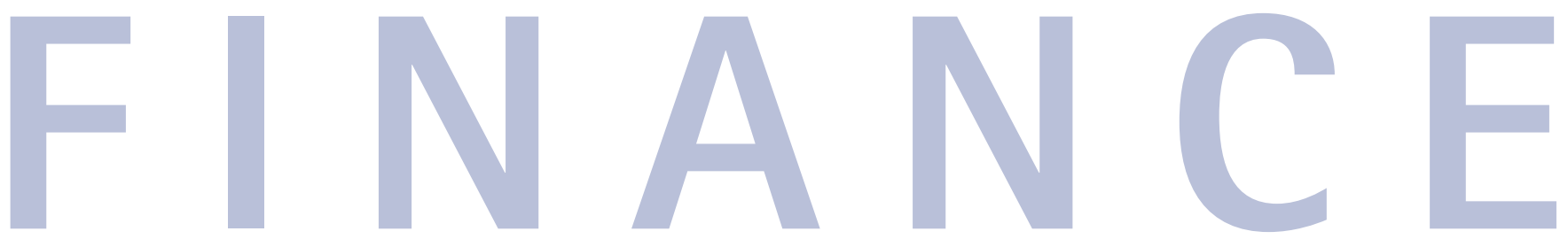

\section{Finance options}

To help control the potentially high initial costs of equipping a new surgery, or refurbishing an established one, The Dental Directory can offer a number of finance options to suit individual needs.

Practices can choose to finance equipment over a period of two to five years either lease hire or lease purchase. The Dental Directory offers finance through most reputable institutions including Siemens, Vector and Braemar. Dentists can choose from a comprehensive range of selected surgery equipment and defer the first payment for six months which allows extra time to establish the surgery and patient numbers and control substantial initial costs.

Reader response number 54

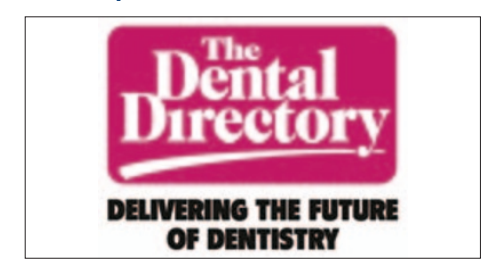

\section{Making the move}

Dental payment plan provider Denplan has launched a new website, www.readyforindependence.com, aimed at supporting dentists wishing to make the transition to independent private practice and highlighting the benefits of Denplan membership.

The website acts as a one-stop shop for dentists wishing to find out more about the numerous benefits already enjoyed by Denplan's 6,500 member dentists.

Products featured include the Denplan Essentials maintenance plan and Denplan Excel accreditation programme.

The new website demonstrates services and expertise and how these can make a valuable difference to practices such as the Denplan Conversion programme, professional development, quality programme, training and marketing support. The site also provides existing Denplan members with information on the range of products and services available to their practice.

Reader response number 56

\section{Spreading the cost}

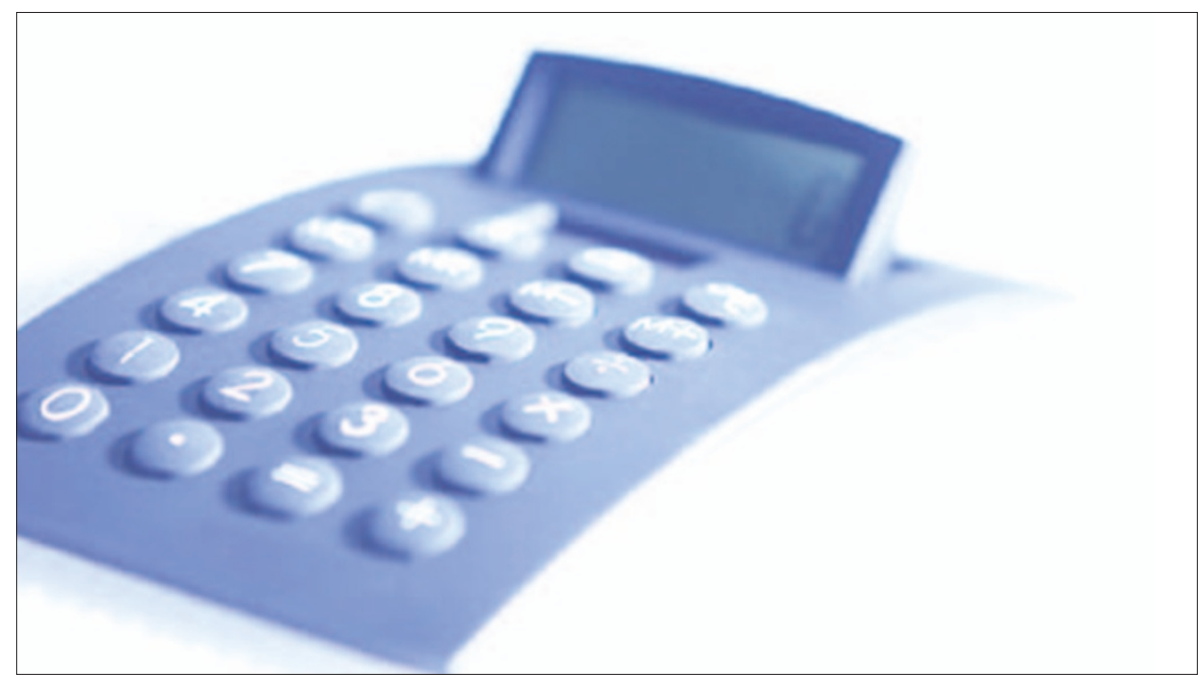

3dee Treatment Funding is a straightforward loan service offered by Frank Taylor and Associates. It encourages patient acceptance of higher value treatment plans and enables patients to spread the cost of dental treatment, up to as much as $£ 15,000$ (or more by special arrangement), over an agreed period of up to five years.

3dee brings to the practice and its patients a number of benefits, including

\section{Sickness and accident protection}

The Dentists' Provident (DPS) offers sickness and accident protection exclusively to qualified dentists throughout the UK and the Irish Republic.

DPS understands the difficulties faced by dentists during illness or after an accident and offers its members insurance to meet their specific needs.

Membership combines protection against accident or illness with a lump sum available at retirement. A monthly payment to the DPS funds a policy designed to accommodate each member's individual needs. Features include an option for benefit payments to commence from the first day of incapacity or after 26 weeks, levelling or reducing of sickness benefits up to age 55, adaptability to changes in a member's circumstances and competitive interest rates, an interest free option or buy now pay later, can increase profits, delivers immediate, upfront payment to the practice and provides comprehensive practice support and staff training.

Taking advantage of an in-house training day ensures that the whole practice team is poised to maximise patient acceptance of 3dee from the outset.

Reader response number 55 the same subscription rates apply for men and women.

For each year of membership members are also entitled to share in any profits made by the Society so from the moment you join the DPS a lump sum is building for your retirement, currently exempt from UK Income and Capital Gains Tax. Dentists' Provident is a mutual organisation with no shareholders so all profits are used for the benefit of members. Reader response number 57

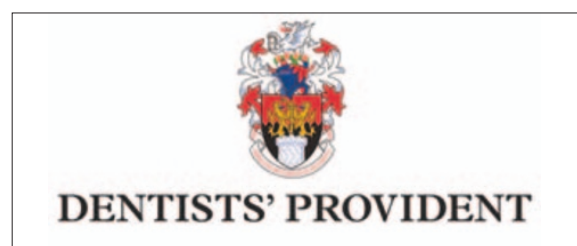




\section{Additional services}

Practice Plan has developed a range of additional, ancillary services to guarantee every customer achieves the maximum benefit from their plan.

Practice Plan's customers receive ongoing support and dedicated advice and guidance. The services offered to clients include dedicated and personalised membership schemes designed to suit each individual practice and guidance on the creation and implementation of a wide range of patient plans, for example a plan designed for children.

It also features calculation and costings for plans, treatments, hourly rate etc, personalised practice logos, brochures, sta- tionery, promotional material, marketing ideas etc, advice and guidance on staff and management issues, in-house training courses for the whole practice team, one day team workshops at various venues around the country and access to a range of consultancy and training services.

Reader response number 58

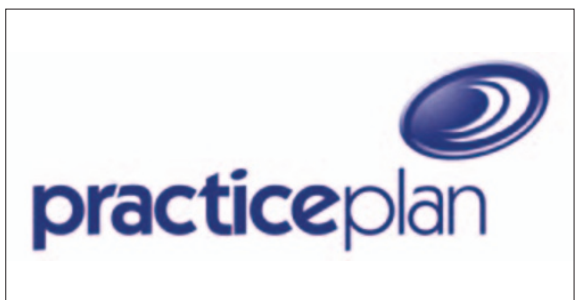

\section{Interest free loans}

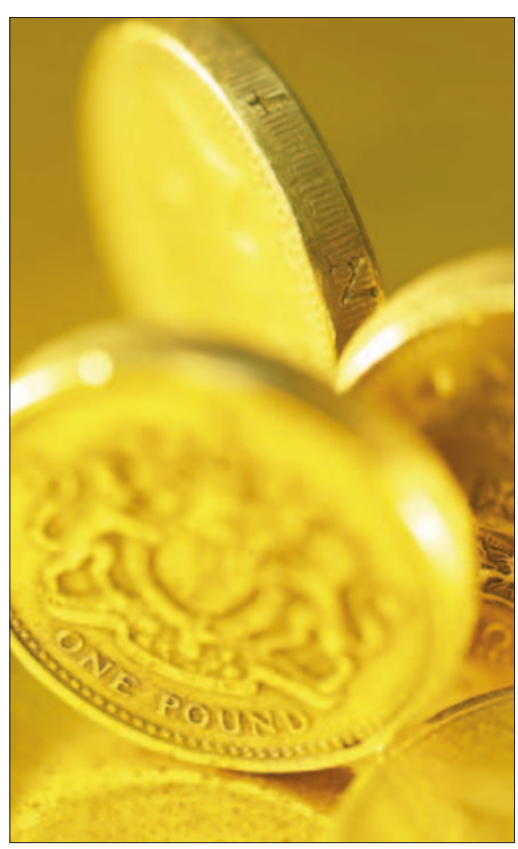

Denplan Enhance enables dentists to offer patients interest-free loans of up to £25,000 for private dental treatment.

The product enables more patients to afford high value dentistry such as implants, cosmetic or orthodontic treatment by spreading the cost over monthly instalments. This can help widen treatment options, increase practice revenue and enable dentists to practise more specialist dentistry. Subject to credit-checks, loans can be offered to all patients, whether Denplan, NHS or private, and treatment can be booked in immediately.

An on-the-spot patient application process allows immediate confirmation of loans from $£ 500$ to $£ 25,000$, repayable by Direct Debit over six to 36 months (depending on the loan term). There are no set-up costs for dentists and patients are not obliged to pay a deposit. Dentists receive their payment up-front and loans are secured without financial risk to the practice.

Reader response number 59

\section{New deal}

Independent practice valuer FTA has formed collaboration with Dentsply which allows its clients to claim up to $£ 5,000$ cash discount on Dentsply products when instructing and receiving an FTA practice valuation.

Dentists can do this by instructing and receiving the practice valuation from an FTA

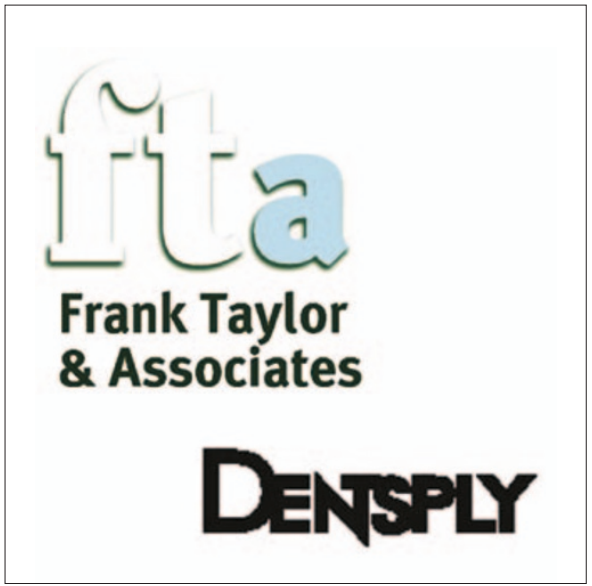
representative. They can then accept 2 vouchers - one for the person who instructed the valuation and the other for the intended purchaser. (Please note: as your practice valuation is strictly confidential, FTA will need authorisation to contact Dentsply for you to benefit from the discount.)

Dentsply will contact you to discuss your requirements and its current offers and you can place your order with your dealer of choice and receive your 5\% discount with a 'cash-back' cheque from Dentsply. You are also entitled to 5 flexichange instruments, free of charge.

Reader response number 60 